\section{Heat-shock Treatments Increase the Chilling Tolerance of Harvested Asparagus Spears}

\author{
Mikal E. Saltveit ${ }^{1}$ \\ Mann Laboratory, Department of Plant Sciences, University of California, \\ Davis, CA 95616-8631
}

Additional index words. Asparagus officinalis, temperature conditioning, postharvest quality, chilling injury

\begin{abstract}
Holding harvested asparagus spears at non-freezing temperatures below $2.5^{\circ} \mathrm{C}$ induces chilling injury (CI), a physiological disorder that reduces quality and shelf life. CI can be quantified by subjective visual parameters, or by objective measurements of the increased rate of ion leakage from excised tissue into an isotonic bathing solution. The rate of ion leakage from apical $(2-3 \mathrm{~cm})$, middle $(9-10 \mathrm{~cm})$, and basal $(15-16 \mathrm{~cm})$ segments excised from 18-cm asparagus spears increased after 7 days of chilling at $2.5^{\circ} \mathrm{C}$. The increase continued and was similar for middle and basal segments after 14 days of chilling, but more pronounced from apical segments. Various heat-shock treatments (i.e., combinations of temperature and duration) decreased the chilling-induced increase in ion leakage from these 1-cm stem segments. Although the chilling tolerance of all spear segments was increased by specific heat-shock treatments, the optimal temperature and duration of exposure varied among the segments; some treatments that were effective in segments from one location were either ineffective or damaging to segments from another location. As the apical half of the whole spear is the predominant culinary portion and contains the most chilling sensitive tissue, heat-shock treatments that would increase the chilling tolerance of the upper half of whole spears were selected for further study. These heat-shock treatments were applied to freshly harvested whole $18-\mathrm{cm}$ asparagus spears that were chilled at $2.5{ }^{\circ} \mathrm{C}$ for 14 days. Two treatment combinations (i.e., $45{ }^{\circ} \mathrm{C}$ for $4.0 \pm 0.6$ minutes or $50{ }^{\circ} \mathrm{C}$ for $2.9 \pm 0.8$ minutes) were identified that maintained the highest level of quality and significantly reduced the rate of chillinginduced ion leakage.
\end{abstract}

Harvested asparagus spears have high rates of respiration (i.e., $\mathrm{CO}_{2}$ production) and should be quickly cooled to 0 to $2{ }^{\circ} \mathrm{C}$ after harvest to maximize quality retention and shelf life (Lill et al., 1990; Lipton, 1990; Luo et al., 2016). Elevated rates of respiration result in the depletion of stored sugars and a progressive increase in spear toughening caused by the synthesis and polymerization of lignin precursors (Albanese et al., 2007). However, asparagus is chilling sensitive and will display morphological changes (e.g., loss of sheen and glossiness and graying of tips, limp, wilted appearance, and darkened spots or streaks near the tips) and physiological changes (e.g., increased membrane permeability, lignification of stem tissue, and increased respiration and ethylene production on warming) after storage at chilling temperatures (i.e., at $2{ }^{\circ} \mathrm{C}$ for $14-21 \mathrm{~d}$ or nonfreezing temperatures near $0{ }^{\circ} \mathrm{C}$ for $10-12 \mathrm{~d}$ ) (Lipton, 1958, 1990). The quality of spears was similar after $23 \mathrm{~d}$ at $5{ }^{\circ} \mathrm{C}$ or $38 \mathrm{~d}$ at $2.2^{\circ} \mathrm{C}$, whereas reducing the temperature to $0^{\circ} \mathrm{C}$ did not increase storage life but actually shortened it to $29 \mathrm{~d}$ because of CI (Lipton, 1990).

Received for publication 26 July 2017. Accepted for publication 5 Oct. 2017.

${ }^{1}$ Corresponding author. E-mail: mesaltveit@, ucdavis.edu.
It appears that spears stored at $0{ }^{\circ} \mathrm{C}$ have lower rates of respiration, but develop greater $\mathrm{CI}$ than those stored at $5{ }^{\circ} \mathrm{C}$, whereas spears stored around $5{ }^{\circ} \mathrm{C}$ become tough more rapidly than those at $0{ }^{\circ} \mathrm{C}$, but develop CI more slowly. The optimum temperature for any duration of storage is, therefore, a compromise between these morphological and physiological changes. Because CI develops slowly, spears should be held near $0{ }^{\circ} \mathrm{C}$ if the storage period will be less than $10 \mathrm{~d}$, or at $2.5^{\circ} \mathrm{C}$ if the storage period will exceed $10 \mathrm{~d}$ (Lipton, 1990; Luo et al., 2016).

Symptoms of chilling can appear during prolonged chilling or during warming after chilling (Saltveit and Morris, 1990). The severity of CI can be quantified by visual inspection of quality parameters, by measuring the rate of ion leakage from excised tissue into an isotonic aqueous bathing solution (King and Ludford, 1983; Murata and Tatsumi, 1979; Saltveit, 1989, 2002; Vickery and Bruinsma, 1973). However, the large and rapid efflux of ions from freshly excised tissue can obscure chilling-induced changes in membrane permeability (Saltveit, 2002). Aging segments at non-chilling temperature $\left(\approx 12.5^{\circ} \mathrm{C}\right)$ overnight $(\approx 12 \mathrm{~h})$ minimizes this problem. Measuring the rate of $\mathrm{CO}_{2}$ production, ethylene production, or both on warming of chilled whole or segmented spears can quantify CI (Saltveit, 1991; Wang, 1982).
For many plants, the level of chilling sensitivity varies among cultivars, growing conditions, seasons, and times of day (Saltveit and Morris, 1990). For example, tomato fruit harvested when cool $\left(19^{\circ} \mathrm{C}\right)$, or warm $\left(32{ }^{\circ} \mathrm{C}\right)$ and cooled $\left(12^{\circ} \mathrm{C}\right)$ for $7 \mathrm{~h}$ before chilling at $2.5{ }^{\circ} \mathrm{C}$ were more chilling tolerant than fruit harvested warm $\left(29^{\circ} \mathrm{C}\right)$ or harvested cool $\left(19^{\circ} \mathrm{C}\right)$ and warmed $\left(32{ }^{\circ} \mathrm{C}\right)$ for $7 \mathrm{~h}$ before chilling (Saltveit and Cabrera, 1987). Tomato plants are more sensitive when chilled in the morning when carbohydrate reserves are low than in the afternoon when carbohydrate reservoirs are high (King et al., 1982, 1988). These observations suggest that chilling sensitivity can be modified by treatments before chilling (i.e., conditioning, hardening).

Various postharvest technologies have been used to extend the shelf life of harvested asparagus. Altering the partial pressure of gases in the storage atmosphere, either through conventional controlled and MA technology (McKenzie et al., 2004; Villanueva et al., 2005) or through hypobaric technology ( $\mathrm{Li}$ and Zhang, 2006) can extend the storage life of harvested green asparagus. Conditioning at elevated temperatures increases the chilling tolerance in some harvested fruit and vegetables (Saltveit and Morris, 1990). However, conditioning usually requires a few days of treatment and such a treatment would severely reduce the quality and shelf life of asparagus. Short-term anoxic treatments (e.g., 6-8 h) at room temperatures $\left(\approx 20\right.$ to $\left.25^{\circ} \mathrm{C}\right)$ also reduce chilling sensitivity and increase the storability of asparagus (Techavuthiporn and Boonyaritthongchai, 2016; Torres-Penaranda and Saltveit, 1994).

Even shorter treatments with a heat-shock (e.g., lasting less than $60 \mathrm{~s}$ ) alter phenolic metabolism in wounded lettuce leaves and celery petioles and decrease tissue browning (Loaiza-Velarde and Saltveit, 2001; LoaizaVelarde et al., 2003). Heat treatments can also prevent the geotropic curvature of harvested asparagus spears (Paull and Chen, 1999). Brief temperature treatments reduce the chilling sensitivity of a number of fruit and vegetables (Wheaton and Morris, 1967). Rapid heat-shock treatments followed by rapid cooling could have an overall beneficial effect on the quality and shelf life of asparagus spears. However, the tissues comprising an asparagus spear vary from delicate meristematic cells near the tip (which are very chilling sensitive) to mature lignified cells near the base (which are much less chilling sensitive), so one treatment combination of duration of exposure to a specific temperature may not be optimal for the entire spear.

Research reported in this article was undertaken for two specific reasons: to study the effect of heat-shock on chilling-induced injury in excised asparagus tissue, and to use this knowledge to develop a heat-shock treatment that would increase the chilling tolerance of whole asparagus spears. Excised and aged $1-\mathrm{cm}$ segments were initially used for four reasons. 1) Ion leakage is more easily measured from segments of tissue smaller 
than a whole $18-\mathrm{cm}$ long asparagus spear. 2) The chilling sensitivity and response to heat-shock treatments can be quantified for specific regions of the spear by using $1-\mathrm{cm}$ segments from different location along the spear. 3) The use of aged segments overcomes the initial trauma of excision that can produce high levels of ion leakage that obscure the smaller changes in leakage associated with chilling-induced changes in membrane permeability. 4) Smaller amounts of tissue are required to evaluate a large number of treatment combinations (e.g., location along spear, temperature of heatshock, duration of heat-shock, and duration of chilling). Heat-shock treatments increased the chilling tolerance of specific tissues within a spear, but the diverse tissues within a spear prevented one heat-shock treatment from being optimal for the entire spear. Because the apical half of the spear is the most chilling sensitive, heat-shock treatments were formulated that would be optimal for the apical portion without damaging the lower portion of the spear.

\section{Materials and Methods}

Plant material. Asparagus (Asparagus officinalis L., cv. UC157) spears were obtained from commercial growers in the Sacramento river delta on the day of harvest, cooled to $10{ }^{\circ} \mathrm{C}$, and transported to the Mann Laboratory where they were sorted to eliminate any defective or injured spears and trimmed to $18 \mathrm{~cm}$ in length. Six randomly selected spears constituted one treatment group. One-centimeter segments were excised from the apex, middle, and base of the spear (i.e., 2-3, 9-10, and 15-16 cm). The six segments from each distance group were washed in a dilute bleach solution (1:20 solution of $5 \%$ sodium hypochlorite) and rinsed in running tap water for $10 \mathrm{~s}$. Excessive moisture was removed by blotting with paper towels, and the six segments in each group were placed in plastic petri dishes $(15 \times$ $100 \mathrm{~mm}$ diameter). The dishes were placed in $20 \times 15 \times 10 \mathrm{~cm}$ translucent plastic tubs lined with wet paper towels, the top of the tubs were loosely covered with aluminum foil, and the tubs were held at $12.5{ }^{\circ} \mathrm{C}$ overnight $(\approx 12 \mathrm{~h})$. Whole 18 -cm long spears were used in later experiments conducted in the Mann Laboratory or at a packing shed within a few hours of harvest.

Temperature treatments. Freshly excised segments were heat shocked by placing the six segments in a nylon mesh bag and immersing the bag in a water bath heated to 30 to $55^{\circ} \mathrm{C}$. The segments were then rinsed in running tap water $\left(\approx 18{ }^{\circ} \mathrm{C}\right)$ for $30 \mathrm{~s}$. The six segments were blotted with paper towels to remove excess moisture and put into plastic petri dishes $(15 \times 100 \mathrm{~mm}$ diameter $)$. The dishes were placed in the aforementioned tubs, and the tubs held at either 12.5 or $2.5^{\circ} \mathrm{C}$ for up to $21 \mathrm{~d}$. The ability of the segments to recover from chilling was studied by holding the tubs containing chilled segments at 2.5 to $12.5^{\circ} \mathrm{C}$ for two additional days.
In experiments with whole spears, six whole $18-\mathrm{cm}$ spears were used as a treatment group and immersed in the water bath. Each group of six spears was one replicate, and there were three replicates per treatment. After rinsing in running tap water for $30 \mathrm{~s}$, the whole spears were blotted dry and bundled in groups of six spears. The spears were placed upright in 1-L wide-mouth glass jars containing $100 \mathrm{~mL}$ of water (about $1.5 \mathrm{~cm}$ in depth). The jars were loosely capped with aluminum foil and held at 2.5 or $12.5^{\circ} \mathrm{C}$.

In later experiments, asparagus spears obtained on the day of harvest from the packing line were immediately immersed in water heated to 40 or $55^{\circ} \mathrm{C}$ for $0-7 \mathrm{~min}$ and then cooled by immersion in $10^{\circ} \mathrm{C}$ water for $10 \mathrm{~min}$. The spears were then evaluated for
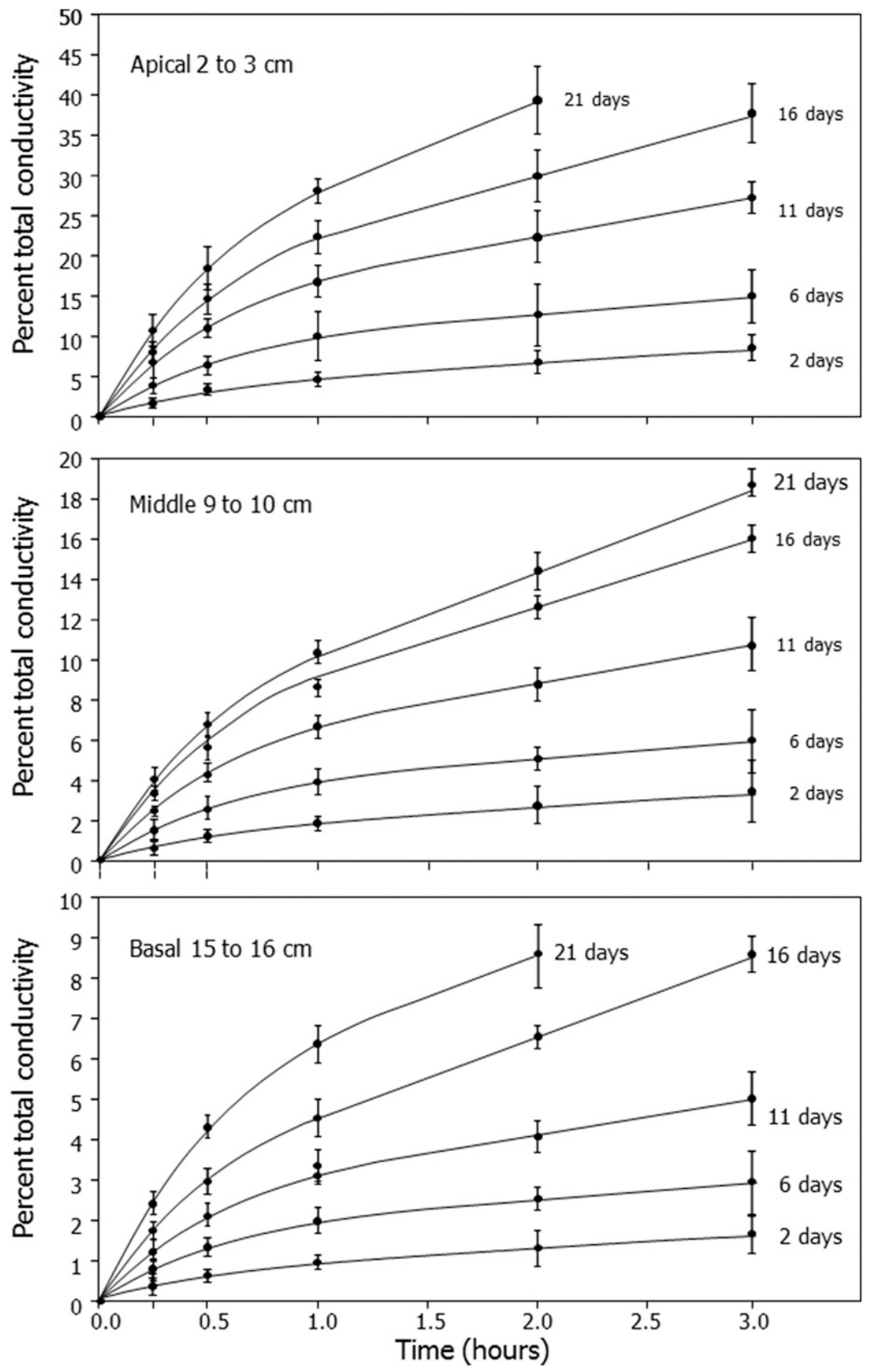

Fig. 1. Ion leakage from excised segments of asparagus spears. Segments were excised $2-3,9-10$, and $15-16 \mathrm{~cm}$ from the tip and were held at $12.5^{\circ} \mathrm{C}$ for $12 \mathrm{~h}$ before being chilled at $2.5^{\circ} \mathrm{C}$ for $2-21 \mathrm{~d}$. Two segments were placed in $20 \mathrm{~mL}$ of an isotonic $0.3 \mathrm{~m}$ mannitol solution and the conductivity of the bathing solution measured periodically for $3.0 \mathrm{~h}$. Total conductivity was measured after two cycles of freezing at $-20{ }^{\circ} \mathrm{C}$ and thawing. The vertical line associated with each data point represents the standard deviation about that mean $(n=6)$. 
initial quality. The cooled spears were transported to the Mann Laboratory at UCD. The groups of six spears were stood upright in 1-L wide-mouth glass jars containing $100 \mathrm{~mL}$ of water (about $1.5 \mathrm{~cm}$ in depth). The jar was capped with a loose fitting piece of aluminum foil. The spears were evaluated for symptoms of CI after being held at $2.5^{\circ} \mathrm{C}$ for $14 \mathrm{~d}$, and again after one additional day at $12.5^{\circ} \mathrm{C}$.

Measurement of CI. Two 1-cm segments from each treatment group were placed in $20 \mathrm{~mL}$ of an isotonic $0.3 \mathrm{~m}$ mannitol solution in a $50-\mathrm{mL}$ plastic centrifuge tube and gently shaken at 120 cycles/min between conductivity measurements as previously described (Saltveit, 2002). Conductivity of the bathing solution was periodically measured for up to $3 \mathrm{~h}$. The tubes were then capped and subjected to two cycles of freezing at $-20{ }^{\circ} \mathrm{C}$ and thawing at room temperature $\left(\approx 20{ }^{\circ} \mathrm{C}\right)$. The final conductivity measurement was taken after bringing the tubes to $20{ }^{\circ} \mathrm{C}$ with shaking for $1 \mathrm{~h}$. Preliminary experiments showed that this freezing/thawing procedure liberated $>98 \%$ of the ions in the tissue (data not shown). The rate of ion leakage was calculated over the linear period and expressed as a percent of the total conductivity per hour.

Quality measurement. The visual quality of the whole spears was subjectively evaluated using a scale wherein excellent quality was rated 9 (no sunken areas on stem, closed tips, and green), fair quality was rated 5 (sunken areas $<1 \mathrm{~cm}$ in length, moderate tip opening, some yellowish areas), and poor quality was rated 1 (most of the stem showing pitting, tip open to expose stem, dull green/ yellow stem). A rating of 7 represented very good quality, whereas a rating of 5 represented a minimal acceptable level of marketable quality. There were six spears per replicate and three replicates per treatment.

Experimental design and data analysis. All experiments were repeated at least twice with similar results, and each treatment was replicated at least twice within each experiment. Six spears in each treatment group (time $\times$ temperature) produced six segments for each location of excision. Ion leakage from these six segments was measured in three groups of two segments each, so within each experiment there were at least 6 values for the computation of each mean and SD. Whole spears were analyzed in groups of six spears per treatment. Data from the heat-shock experiments were subjected to an analysis of variance and least significant difference calculated when significant at the 5\% level were detected.

\section{Results and Discussion}

Ion leakage from excised asparagus tissue. The conductivity of the isotonic bathing solution containing the apical $(2-3 \mathrm{~cm})$, middle $(9-10 \mathrm{~cm})$, and basal $(15-16 \mathrm{~cm})$ excised spear segments increased rapidly during the first $30 \mathrm{~min}$, increased more slowly for an additional $30 \mathrm{~min}$ and then increased linearly for the next $2 \mathrm{~h}$ (Fig. 1). This increase was most pronounced from the apical segments, but a similar, although smaller increase occurred from tissue from the other two locations. The kinetics of ion leakage into the bathing solution from the aged excised segments was surprisingly similar among tissues from the three locations and from all chilling treatments; differing only in magnitude. It followed a pattern previously described (Saltveit, 2002).

Getting accurate measurements of ion leakage from freshly excised tissue is problematic since excision of the tissue itself causes changes in membrane permeability and releases large quantities of ions from the cut surfaces (Saltveit, 1989). Aging the excised tissue overnight $(\approx 12 \mathrm{~h}$ ) at a non-chilling


Fig. 2. Ion leakage from excised segments of asparagus spears. Segments excised 9-10 cm from the tip were (A) held at $12.5{ }^{\circ} \mathrm{C}$ for $12 \mathrm{~h}$, before being (B) chilled at $2.5^{\circ} \mathrm{C}$ for $14 \mathrm{~d}$, and then $(\mathbf{C})$ held at $12.5^{\circ} \mathrm{C}$ for $2 \mathrm{~d}$. The tangential dashed line is an extension of the linear portion of the leakage curve back to its intersection with the $y$-axis. The intersection of the horizontal dashed line with the $y$-axis indicates the apoplastic component of ion leakage. Conductivity was measured as described above. The vertical line associated with each data point represents the standard deviation about that mean $(n=6)$. 
temperature $\left(\approx 12.5{ }^{\circ} \mathrm{C}\right)$ reduced both the initial rate of leakage and its variation among the segments, but did not significantly alter the pattern of ion leakage into the bathing solution (Fig. 2). The rate of leakage after $1 \mathrm{~h}$ in the isotonic solution was linear until at least $2.6 \mathrm{~h}$, and this linearity was consistent among tissue taken from the three locations; although the slope of this linear increase in conductivity was greater from tissue excised nearer the tip (Fig. 1). However, this aging procedure rendered the results less applicable to actual commercial applications, so beneficial time $\times$ temperature combinations were verified with freshly harvested whole $18-\mathrm{cm}$ long spears in later experiments.

The slope of the linear portion of the curve represents leakage through cellular membranes and therefore indicates changes in membrane permeability brought on by chilling, while the $y$-intercept represents the ions freely exchangeable from the apoplastic regions of the tissue (Saltveit, 1989, 2002). Chilling increased the $y$-intercept of the linear regression line from $1.8 \%$ to $8.4 \%$ of total conductivity (Fig. 2A and B). The increase in apoplastic ion content during chilling indicates that not only does the permeability of the cell membrane increase, but that the ability of the cell to reabsorb the leaked ions is also greatly diminished.

If the extent of chilling (i.e., duration $x$ temperature) is not so damaging as to prevent recovery, then the rapid increase in respiration upon warming is accompanied by reabsorption of the apoplastic ions and a reestablishment of cellular permeability (Fig. 2C; Saltveit, 2002). The apoplastic component decreased from $8.4 \%$ to $3.9 \%$ of total conductivity upon recovery. The slope of the linear increase in conductivity increased upon chilling from $0.77 \%$ to $2.03 \%$ of total conductivity per hour. Upon recovery, it decreased to 1.48. While this was a significant decrease which indicated recovery of membrane semipermeability, the recovered rate was still almost double the rate before chilling. The ability of chilled tissue to recover normal function upon warming is the basis by which intermittent warming ameliorates $\mathrm{CI}$.

Ion leakage from chilled tissue. The rate of ion leakage increased slightly from excised segments from all locations as the duration of chilling at $2.5{ }^{\circ} \mathrm{C}$ increased from 0 to $6 \mathrm{~d}$ (Fig. 3). Extending the duration of chilling to $15 \mathrm{~d}$ produced greater increases in the rate of ion leakage from apical tissue than from either middle or basal tissue segments. It was obvious that apical tissue was far more chilling sensitive than tissue from the middle or basal regions of the spear. While the middle and basal segments were composed almost entirely of fully expanded cells making up the stem tissue, apical segments were composed of more varied tissues; i.e., bracts, buds at nodes, and stem tissue at various stages of cellular expansion.

Effect of heat-shock on the rate of ion leakage from chilled tissue. In some treatments,

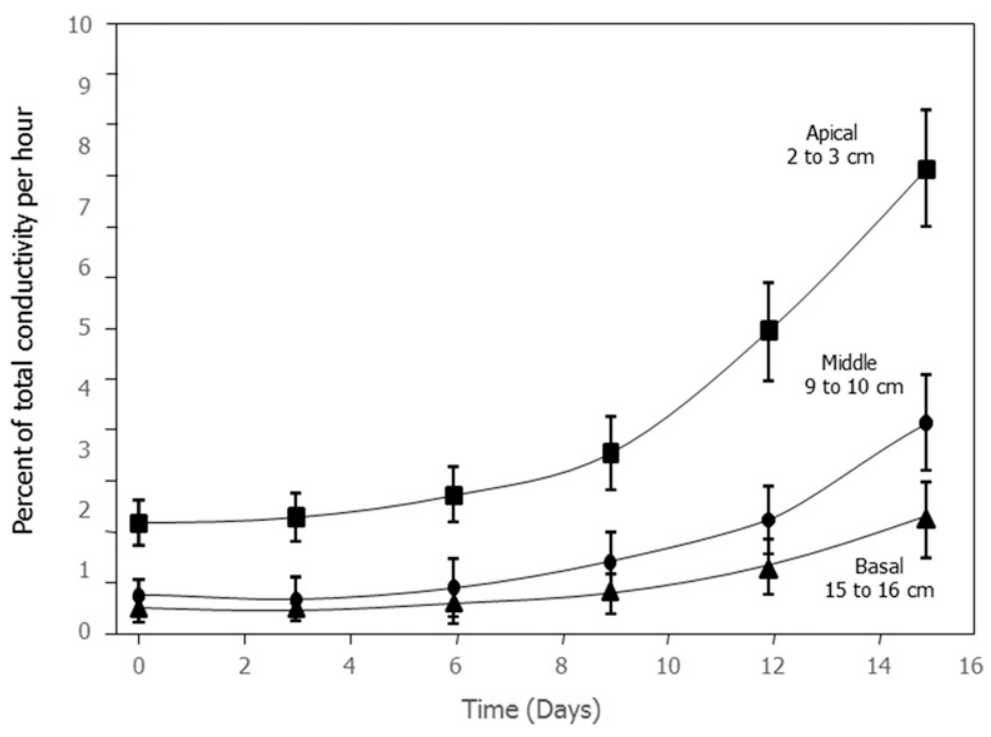

Fig. 3. Effect of chilling on the rate of ion leakage from excised segments of asparagus spears. Segments excised 2-3, 9-10, and 15-16 cm from the tip were held at $12.5^{\circ} \mathrm{C}$ for $12 \mathrm{~h}$, before being chilled at $2.5^{\circ} \mathrm{C}$ for up to $15 \mathrm{~d}$. Conductivity was measured as described above. The vertical line associated with each data point represents the standard deviation about that mean $(n=6)$.
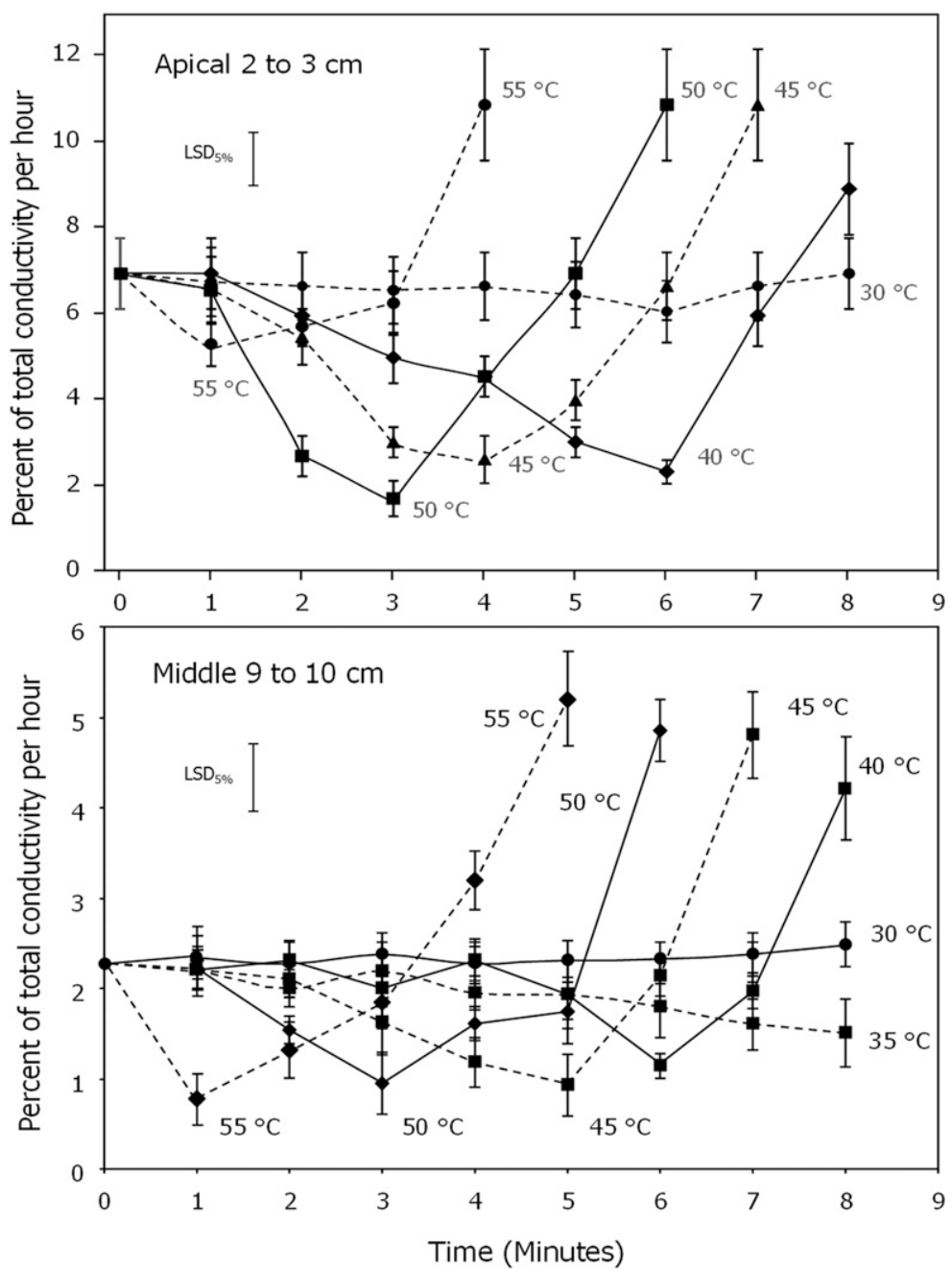

Fig. 4. Effect of heat shock on the rate of ion leakage from excised segments of asparagus spears. Segments excised 2-3, and 9-10 $\mathrm{cm}$ from the tip were immersed in heated water for up to $8 \mathrm{~min}$. Segments were then chilled at $2.5{ }^{\circ} \mathrm{C}$ for $14 \mathrm{~d}$. Conductivity was measured as described above. The vertical line associated with each data point represents the standard deviation about that mean $(n=3)$, while the vertical bar in each panel indicate the least significant difference (LSD) at $P<0.05$. 
immersing asparagus spear segments in water from 20 to $55^{\circ} \mathrm{C}$ for $0-8$ min significantly altered the ability of chilling to increase the rate of ion leakage (Fig. 4). Many of the treatments (i.e., temperature $x$ duration) had no significant effect on the ability of chilling to increase the rate of ion leakage; all duration at 20 or $30^{\circ} \mathrm{C}$ were designated the "control" levels. However, other treatments either greatly increased the rate of ion leakage (e.g., $55^{\circ} \mathrm{C}$ for 4 or $5 \mathrm{~min}, 50^{\circ} \mathrm{C}$ for $6 \mathrm{~min}, 45^{\circ} \mathrm{C}$ for $7 \mathrm{~min}$, or $40^{\circ} \mathrm{C}$ for $8 \mathrm{~min}$ ) above the control level, or significantly reduced the rate of ion leakage (e.g., $50{ }^{\circ} \mathrm{C}$ for $3 \mathrm{~min}, 45^{\circ} \mathrm{C}$ for 4 or $5 \mathrm{~min}$, or $40{ }^{\circ} \mathrm{C}$ for $6 \mathrm{~min}$ ) below the control level. Apical segments were more sensitive than middle segments to heating, with $1 \mathrm{~min}$ of $55^{\circ} \mathrm{C}$ having a protective effect in middle tissue, but no protective effect at any duration in apical tissue.

Although there appeared to be a threshold temperature around $35{ }^{\circ} \mathrm{C}$ that had to be exceeded to elicit a physiological response, the exact response (either positive or negative) depended on the source of the tissue and on the temperature and duration of exposure (Fig. 4). For example, exposure to $50{ }^{\circ} \mathrm{C}$ for 3 min significantly reduced subsequent chilling-induced ion leakage in both apical and middle tissue, while extending the duration of exposure to 5 or 6 min either produced no protection, or actually damaged the tissue as shown by the increased rate of ion leakage. These experiments with excised segments delineated the possible treatments that would be effective in increasing the chilling tolerance of whole asparagus spears.

Effect of heat-shock on the visual quality of chilled spears. Whole 18-cm long spears were subjected to a variety of temperature and duration combinations before being chilled at $2.5^{\circ} \mathrm{C}$ for $14 \mathrm{~d}$ (Fig. 5). Quality scores from the 20,30 and $35^{\circ} \mathrm{C}$ treatments did not improve (data not shown in Fig. 5 for clarity of presentation). Results of the subjective evaluation of spear quality were similar to that of the ion leakage measurements (Fig. 4). As the temperature of the treatment increased, the duration of immersion needed to produce a physiological response decreased (Fig. 5). The maximum beneficial effect at 40,45 , and $50{ }^{\circ} \mathrm{C}$ accrued from a 6,4 , and $3 \mathrm{~min}$ of immersion, respectively. However, durations of immersion exceeding these optimal times rapidly negated any beneficial effect on the quality retention of chilled spears.

Ion leakage from $1-\mathrm{cm}$ segments $(9-10 \mathrm{~cm}$ from the tip) excised from the whole spears evaluated in Fig. 5, showed a strong biphasic response (Fig. 6). Spears with higher quality scores had significantly lower rates of ion leakage than did poorer quality spears. As the quality of the spears declined from 8.4 to 2.4 , there was a linear increase $\left(r^{2}=0.89\right)$ from 0.88 to 2.3 in the percent of total conductivity. The rate of ion leakage from segments excised from spears with quality scores below 2.4 showed a much greater increase in ion leakage with further minor reductions in quality. Measurement of ion leakage from aged spear segments may be an effective method to gauge subsequent market life.
An effective treatment. Because most of the observable symptoms of CI appeared in the upper half of the spear (i.e., the predominant

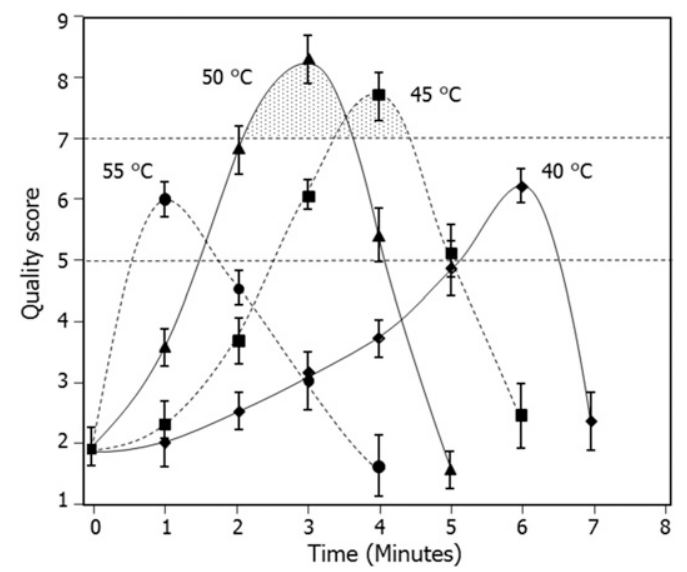

Fig. 5. Effect of chilling and heat shock on the quality of whole asparagus spears. The whole spears $(18-\mathrm{cm}$ long) were immersed in heated water for up to $7 \mathrm{~min}$ before being chilled at $2.5^{\circ} \mathrm{C}$ for $14 \mathrm{~d}$. The quality of the whole asparagus spears were evaluated as described, and 1-cm segments were excised 9-10 cm from the tip for leakage measurements (see Fig. 6). The shaded area indicates quality levels above seven for the 45 and $50{ }^{\circ} \mathrm{C}$ curves. The vertical line associated with each data point represents the standard deviation about that mean $(n=6)$.

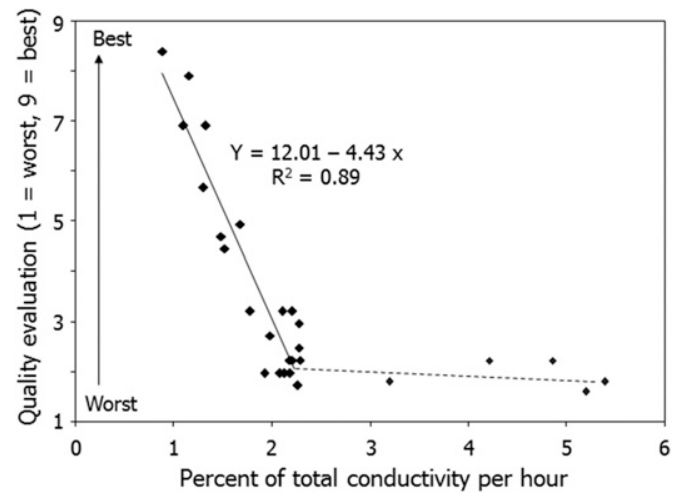

Fig. 6. Relationship between the rate of ion leakage and quality of chilled spears. The quality of $18 \mathrm{~cm}$ long asparagus spears were evaluated (Fig. 5) and then 1-cm segments were excised 9-10 cm from the tip and held at $12.5^{\circ} \mathrm{C}$ for $12 \mathrm{~h}$. Conductivity was measured as described above.

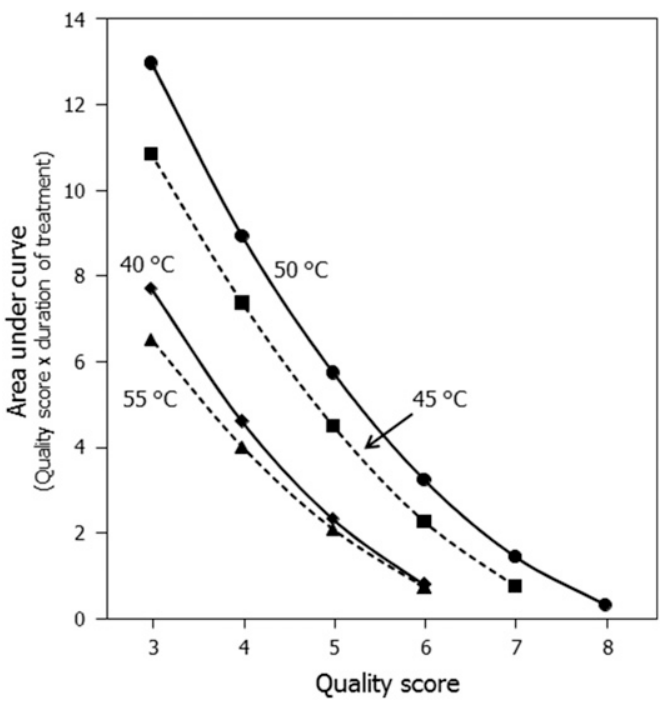

Fig. 7. Area under the curves of quality of whole spears vs. time of immersion. The area was calculated from integrating a fifth-degree polynomial equation fitted to each temperature curve in Fig. 5. 
culinary portion of the spear), treatments were selected that focus on maintaining quality in the upper portion of the spear. Treatments were also selected that maximize the possibility of inducing a protective heat-shock response while minimizing the possibility of producing deleterious effects through a combination of excessive temperature and/or duration of immersion. These strictures can be fulfilled by computing the area under the response curves above a minimally acceptable quality for the various heat-shock treatments (Fig. 5).

A fifth-degree polynomial with an $r^{2}>$ 0.98 was fitted to each temperature curve above a quality score of 2.0 (see Fig. 5). Each equation was integrated to compute the area under the curve. The two time values ( $x$-axis time values corresponding to a level of $y$-axis quality) were computed for each quality level and the area of the rectangle delimited by these coordinates was subtracted from the total integrated area to give the area under the curve above the designated quality scores from 9.0 to 2.0. As the lower limit of acceptability decreased from 9.0 to 2.0 , the area under the curve increased (Fig. 7). The area under the curve and above each quality score was greatest for $50^{\circ} \mathrm{C}$, and slightly less for $45{ }^{\circ} \mathrm{C}$ at each quality score. The area under either the 40 or $55{ }^{\circ} \mathrm{C}$ curves were similar to each other, and less than the area under either the 45 or $50{ }^{\circ} \mathrm{C}$ quality curves.

\section{Conclusion}

In a commercial operation, the utility of a treatment not only depends on its optimal effectiveness, but on the sensitivity of the treatment to slight variation in the optimal treatment temperature and duration. Repeated derivativization of the fifth-degree polynomial produced the maximum inflection point for each curve at $6.1,4.0$, and $2.9 \mathrm{~min}$ of immersion for 40,45 , and $50{ }^{\circ} \mathrm{C}$, respectively (Fig. 5). If we assume that a quality score of 7.0 is the desired marketable quality, then the areas under the 45 and $50{ }^{\circ} \mathrm{C}$ curves that exceed this level are 0.8 units (quality score $\times$ minutes) for $45^{\circ} \mathrm{C}$, and 1.8 units for $50{ }^{\circ} \mathrm{C}$ (see the shaded areas under the 45 and $50{ }^{\circ} \mathrm{C}$ curves in Fig. 5). The other two temperature treatments were unable to maintain quality above 7.0. The width of these curves at a quality of 7.0 is 1.3 and $1.6 \mathrm{~min}$ for 45 and $50{ }^{\circ} \mathrm{C}$, respectively. The curves are roughly symmetric about these inflection points, so immersing whole spears in water at $45^{\circ} \mathrm{C}$ for $4.0 \pm 0.6 \mathrm{~min}$ or $50^{\circ} \mathrm{C}$ for $2.9 \pm 0.8$ min could provide optimal chilling resistance under the conditions described in this paper.

\section{Literature Cited}

Albanese, D., L. Russo, L. Cinquanta, A. Brasiello, and M. Di Matteo. 2007. Physical and chemical changes in minimally processed green asparagus during cold-storage. Food Chem. 101:274280.

King, A.I., D.C. Joyce, and M.S. Reid. 1988. Role of carbohydrates in diurnal chilling sensitivity to tomato seedlings. Plant Physiol. 86:764-768.

King, A.I., M.S. Reid, and B.D. Patterson. 1982. Diurnal changes in the chilling sensitivity of seedlings. Plant Physiol. 70:211-214.

King, M.M. and P.M. Ludford. 1983. Chilling injury and electrolyte leakage in fruit of different tomato cultivars. J. Amer. Soc. Hort. Sci. 108:74-77.

Li, W. and M. Zhang. 2006. Effect of three-stage hypobaric storage on cell wall components, texture and cell structure of green asparagus. J. Food Eng. 77:112-118.

Lill, R.E., G.A. King, and E.M. O’Donoghue 1990. Physiological changes in asparagus spears immediately after harvest. Sci. Hort. 44:191199.

Lipton, W.J. 1958. Effect of temperature on asparagus quality. Proc. Conf. Transport. Perishables, Univ. Calif., Davis, 3-5 Feb. 1958. p. 147-151.

Lipton, W.J. 1990. Postharvest biology of fresh asparagus. Hort. Rev. 12:69-155.

Loaiza-Velarde, J.G., M.E. Mangrich, R. CamposVargas, and M.E. Saltveit. 2003. Heat-shock reduces browning of fresh-cut celery petioles. Postharvest Biol. Technol. 27:305-311.

Loaiza-Velarde, J.G. and M.E. Saltveit. 2001. Heat shocks applied either before or after wounding reduce browning of lettuce leaf tissue. J. Amer. Soc. Hort. Sci. 126(2):227-234.

Luo, Y., T. Suslow, and M. Cantwell. 2016. Asparagus, p. 210-213. In: K.C. Gross, C.Y. Wang, M.E. Saltveit (eds.). The commercial storage of fruits, vegetables, and florist and nursery stocks. USDA, ARS Agriculture Handbook 66. $<$ https://www.ars.usda.gov/ARSUserFiles/oc/np/ CommercialStorage/CommercialStorage.pdf $>$.
McKenzie, M.J., L.A. Greer, J.A. Heyes, and P.L. Hurst. 2004. Sugar metabolism and compartmentation in asparagus and broccoli during controlled atmosphere storage. Postharvest Biol. Technol. 32:45-56.

Murata, T. and Y. Tatsumi. 1979. Ion leakage in chilled plant tissues, p. 141-151. In: J.M. Lyons, D. Graham, and J.K. Raison (eds.) Low temperature stress in crop plants. Academic Press, New York.

Paull, R.E. and N.J. Chen. 1999. Heat treatment prevents postharvest geotropic curvature of asparagus spears (Asparagus officinalis C.). Postharvest Biol. Technol. 16:37-41.

Saltveit, M.E. 1989. A kinetic examination of ion leakage from chilled tomato pericarp disks. Acta Hort. 258:617-622.

Saltveit, M.E. 1991. Prior temperature exposure affects subsequent chilling sensitivity. Physiol. Plant. 82:529-536.

Saltveit, M.E. 2002. The rate of ion leakage from chilling-sensitive tissue does not immediately increase upon exposure to chilling temperatures. Postharvest Biol. Technol. 26:295-304.

Saltveit, M.E. and R.M. Cabrera. 1987. Tomato fruit temperature before chilling influences ripening after chilling. HortScience 22:452-454.

Saltveit, M.E. and L.L. Morris. 1990. Overview of chilling injury of horticultural crops, p. 3-15. In: C.Y. Wang (ed.). Chilling injury of horticultural crops. CRC Press, Boca Raton, FL.

Techavuthiporn, C. and P. Boonyaritthongchai. 2016. Effect of prestorage short-term anoxia treatment and modified atmosphere packaging on the physical and chemical changes of green asparagus. Posthav. Biol. Technol. 117: 64-70.

Torres-Penaranda, A.V. and M.E. Saltveit. 1994. Effect of brief anaerobic exposures on carbon dioxide production and quality of harvested asparagus. J. Amer. Soc. Hort. Sci. 119:551-555.

Vickery, R.S. and J. Bruinsma. 1973. Compartments and permeability for potassium in developing fruits of tomato (Lycopersicon esculentum Mill.). J. Expt. Bot. 24:1261-1270.

Villanueva, M.J., M.D. Tenorio, M. Sagardoy, A. Redondo, and M.D. Saco. 2005. Physical, chemical, histological and microbiological changes in fresh green asparagus (Asparagus officinalis, L.) stored in modified atmosphere packaging. Food Chem. 91:609-619.

Wang, C.Y. 1982. Physiological and biochemical responses of plants to chilling. HortScience 17:173-186.

Wheaton, T.A. and L.L. Morris. 1967. Modification of chilling sensitivity by temperature conditioning. Proc. Amer. Soc. Hort. Sci. 91:529-533. 